\title{
Removal of micropollutants through a biological wastewater treatment plant in a subtropical climate, Queensland-Australia
}

\author{
Miguel Antonio Reyes Cardenas ${ }^{1}$, Imtiaj Ali ${ }^{2}$ Foon Yin Lai ${ }^{3}$, Les Dawes ${ }^{4}$, Ricarda Thier ${ }^{5}$ and Jay Rajapakse ${ }^{4^{*}}$
}

\begin{abstract}
Background: Municipal wastewaters contain a multitude of organic compounds derived from domestic and industrial sources including active components of pharmaceutical and personal care products and compounds used in agriculture, such as pesticides, or food processing such as artificial sweeteners often referred to as micropollutants. Some of these compounds or their degradation products may have detrimental effects on the environment, wildlife and humans. Acesuflame is one of the most popular artificial sweeteners to date used in foodstuffs. The main objectives of this descriptive study were to evaluate the presence of micropollutants in both the influent and effluent of a large-scale conventional biological wastewater treatment plant (WWTP) in South-East Queensland receiving wastewater from households, hospitals and various industries.

Methods: Based on USEPA Method 1694: Filtered samples were spiked with mass-labelled chemical standards and then analysed for the micropollutants using liquid chromatography coupled with tandem mass spectrometry.

Results: The presence of thirty-eight compounds were detected in the wastewater influent to the treatment plant while nine of the compounds in the categories of analgesic, anti-inflammatory, alkaloid and lipid/cholesterol lowering drugs were undetectable (100\% removed) in the effluent. They were: Analgesic: Paracetamol, Salicylic acid, Oxycodone; Anti-inflammatory: Naproxen + ve, Atorvastatin, Indomethacin, Naproxen; Alkaloid: Caffeine; Lipid/cholesterol lowering: Gemfibrozol.

Conclusions: The study results revealed that the micropollutants removal through this biological treatment process was similar to previous research reported from other countries including Europe the Americas and Asia, except for acesulfame, a highly persistent artificial sweetener. Surprisingly, acesulfame was diminished to a much greater extent (>90 \%) than previously reported research for this type of WWTPs (45-65\%) that only include physical removal of objects and solids and a biodegradation step.
\end{abstract}

Keywords: Biological wastewater treatment, Micropollutants removal, Sub-tropical climate

\section{Background}

Health and environmental concerns about the effects of micropollutants in wastewater have become increasingly important in wastewater management. The term microconstituents includes pharmaceuticals and personal care products (PPCPs), and other compounds that may be found in wastewater in small amounts including compounds used in food processing and agriculturally used

* Correspondence: jay.rajapakse@qut.edu.au

${ }^{4}$ Science and Engineering Faculty, School of Earth, Environment and Biological Sciences, Queensland University of Technology, QLD 4001 Brisbane, Australia

Full list of author information is available at the end of the article pesticides. Public concern increases particularly in situations where wastewater effluent is released into the environment (e.g., streams and rivers) that are then used as a raw potable water source for communities located downstream [1]. This especially concerns countries in Europe, where recycled water is used not only for agricultural purposes but also for preparation of drinking water. Water usage has become highly critical in other countries as well. For example, several states in Australia are committed to recycle more water in the future due to Australia's general arid climate, frequent droughts and other pressures. Local governments are searching for strategies to 
minimise micropollutant release into surface waters and/ or increase of removal from wastewater, in order to ensure the health of humans and their ecosystem [2].

As of 2006, there are about 50,000 chemicals used for industrial, agricultural and veterinary purposes in Australia [3]. Since the early 1990s, chemical assessments have taken place which resulted in the creation of different strategies and regulations for the utilisation and manipulation of pesticides, medicines, and so forth [4]. The National Industrial Chemicals Notification and Assessment Scheme (NICNAS) and the Therapeutic Goods Administration are examples of regulators created to control the use and disposal of industrial chemicals and pharmaceuticals, respectively. Significant questions remain about the types and levels of monitoring of treatment processes required in order to adequately protect human health and the environment.

The three largest sources of PPCPs include industry, hospitals, and private homes. PPCPs enter into the sanitary sewer primarily through excretion of un-metabolised pharmaceuticals [5]. Table 1 shows urinary excretion percentage as parent compound of some of the most common pharmaceuticals found in sewerage systems. In addition, residual products are frequently discarded via the sewerage system. For example, the results from a survey of the American public found that only $1.4 \%$ of the surveyed people returned unused medication to the pharmacy, whereas $54 \%$ threw them away and $35.4 \%$ disposed them in the sink or the toilet [6]. Another source of these compounds are uncontrolled landfill sites where they and their chemical or biological degradation products reach nearby rivers or groundwater as surface run off or leachate [7]. Surface run-off may also contain chemicals from agricultural activity such as pesticides and animal medicines [8].

Recently, artificial sweeteners (ASs) have been identified as emerging environmental contaminants [9-13]. ASs are widely used in foods, particularly beverages, as sugar substitutes and are excreted mainly unmetabolised. They are excreted via the kidney and reach surface waters of the environment mainly in this unchanged form [11-13].

Table 1 Percentage of drug found in urinary excretion as parent compound for common medicines

\begin{tabular}{llll}
\hline Drug & Class & $\begin{array}{l}\text { Compound } \\
\text { excreted (\%) }\end{array}$ & References \\
\hline Ibuprofen & $\begin{array}{l}\text { Non-steroidal } \\
\text { anti-inflammatory (NSAID) }\end{array}$ & 10 & {$[53]$} \\
Paracetamol & Painkiller & 4 & {$[54]$} \\
Erythromycin & Antibacterial & 25 & {$[54]$} \\
Sulfamethoxazole & Antibacterial & 15 & {$[55]$} \\
Atenolol & $\beta$ - blocker & 90 & {$[53]$} \\
Metoprolol & $\beta$ - blocker & 10 & {$[54]$} \\
Carbamazepine & Antiepileptic & 3 & {$[54]$} \\
\hline
\end{tabular}

Acesulfame (ACE) is one of these sugar substitutes found in the aquatic environment as a result of effluents containing $\mathrm{ACE}$ from wastewater treatment plants being discharged into water courses. Acesulfame concentrations in the wastewater treatment plant effluents were reported from as low as $20 \mu \mathrm{g} / \mathrm{L}$ [14] up to very high values as $2.5 \mathrm{mg} / \mathrm{L}[11-13,15]$. It is so persistent that on the one hand, it has raised concern as an environmental pollutant but on the other hand, it is appreciated as a marker for contamination of e.g., groundwater with domestic wastewater [12, 16]. However, as Lange et al. [12] identified the actual knowledge about environmental persistence and potential hazard of ACE is not well understood.

The impact of most micropollutants on human health and environment is not well understood. However, effects of some PPCPs on human health and environment are known. For example triclosan, an antibacterial and antifungal used in personal care products such as soap and tooth paste, is called an endocrine disrupting compound (EDC) because it interferes with natural hormonal functions, potentially altering metabolism, development, reproduction and growth [17] including decline in reproductive function in men [18]. Effects of EDCs on the environment comprise birth abnormalities and feminisation of organisms including fish, frogs, birds and mammals [4]. Effects on aquatic organisms have also been documented for certain herbicides, such as 2,4-Dichlorophenoxyacetic acid $(2,4 \mathrm{D})$, which alters the shell formation of the bivalve Anodonta cygnea [16]. This compound has also been investigated intensely for chronic toxicity in humans but results remained inconclusive [19].

Some water micro-constituents, such as the antibiotic ciprofloxacin and the artificial sweetener acesulfame, have been shown to be degraded during certain treatment steps, which can lead to conversion into more toxic compounds $[9,20]$. Antibacterials are of concern not only because of their toxicity but also as harbinger of bacterial resistance. Bacteria in wastewater comprise very high levels and varieties of resistance genes, which may be disseminated to human and animal pathogens [21-23]. Multi-resistance in bacteria is a major global health issue that has further restricted treatment options for already limited options of infectious diseases [24].

There is only limited knowledge around the accumulative effects of individual compounds and combination effects of mixtures of micropollutants in wastewater. Some advances in this field have been made with the consideration of toxic equivalent concentrations and the use of mode of action based test batteries where concentrated water samples are tested and the risk is assessed by comparing the results of e.g., environmental water samples to specific reference compounds for each test [25-27]. Advanced methods of water treatment have been designed 
for reclamation of wastewater for drinking purposes including reverse osmosis, ozonation, UV-irradiation, nanoand ultrafiltration, activated carbon filter and biofiltration. When applied after traditional wastewater treatment these techniques reduce a wide variety of biological effects including estrogenic, genotoxic, neurotoxic and phytotoxic effects. These reduction of these effects varied depending on the treatment combined with the compound composition of the water [28-30].

In summary, it becomes clear that additional steps for wastewater treatment are essential to decrease the discharge of micropollutants [31] into Australian rivers and estuaries as current traditional wastewater treatment is insufficient to avoid their release into the environment. In South-East Queensland, several studies have investigated the removal of micropollutants in modern state of the art water reclamation plants [27-30]. These studies have focussed on the removal of micropollutants with sophisticated methods. Furthermore, in the South-East Queensland region, Shareef et.al [32] investigated the removal of EDCs and PPCPs at Oxley Creek and Luggage Point which received wastewater from domestic and domestic/industrial sources respectively. Ying et al. [33] studied the estrogens and xenoestrogens removal in the final effluents of five wastewater treatment plants from South-East Queensland. Also, Tan et al. [34] did a comprehensive study of the removal of 15 EDCs and estrogen equivalent (EEqs) of five wastewater treatment plants from South-East Queensland. Two other studies have investigated the fate of antibacterials and these were used for comparison where appropriate $[35,36]$.
This paper assesses the efficiency of conventional wastewater management practices on the removal of PCPPs and other micropollutants in a traditional 3-step WWTP in South-East Queensland to inform future individual wastewater management plans for this WWTP. The concentrations of 95 different micropollutants in wastewater influent and effluent were determined. Removal rates for the biodegradation step were calculated for compounds that were found in the influent.

\section{Methods}

Description of the wastewater treatment plant

The municipal wastewater treatment plant (WWTP) receives wastewater mainly from households, hospitals and various manufacturing and service industries including meat manufacturing, automobile repairing and maintenance, fuel retailing, laundry and dry cleaning and spirit manufacturing.

The WWTP is equipped with a conventional 3-step treatment process including physical removal of objects and solids, biological oxidation and a chlorine based disinfection process (Fig. 1). Preliminary treatment involves three band screens and two grit chambers, which removes grit and screenings. Sodium hypochlorite $(\mathrm{NaOCl})$ and sodium hydroxide $(\mathrm{NaOH})$ are used in the preliminary treatment for odour control and $\mathrm{pH}$ adjustments. The system has a fully automated wet weather by pass system to send excess flow into environment (a receiving stream). The biological process integrates four oxidation ditches (OD) with an aerobic and anaerobic zone followed by clarifiers. The sludge dewatering facility consists of a gravity

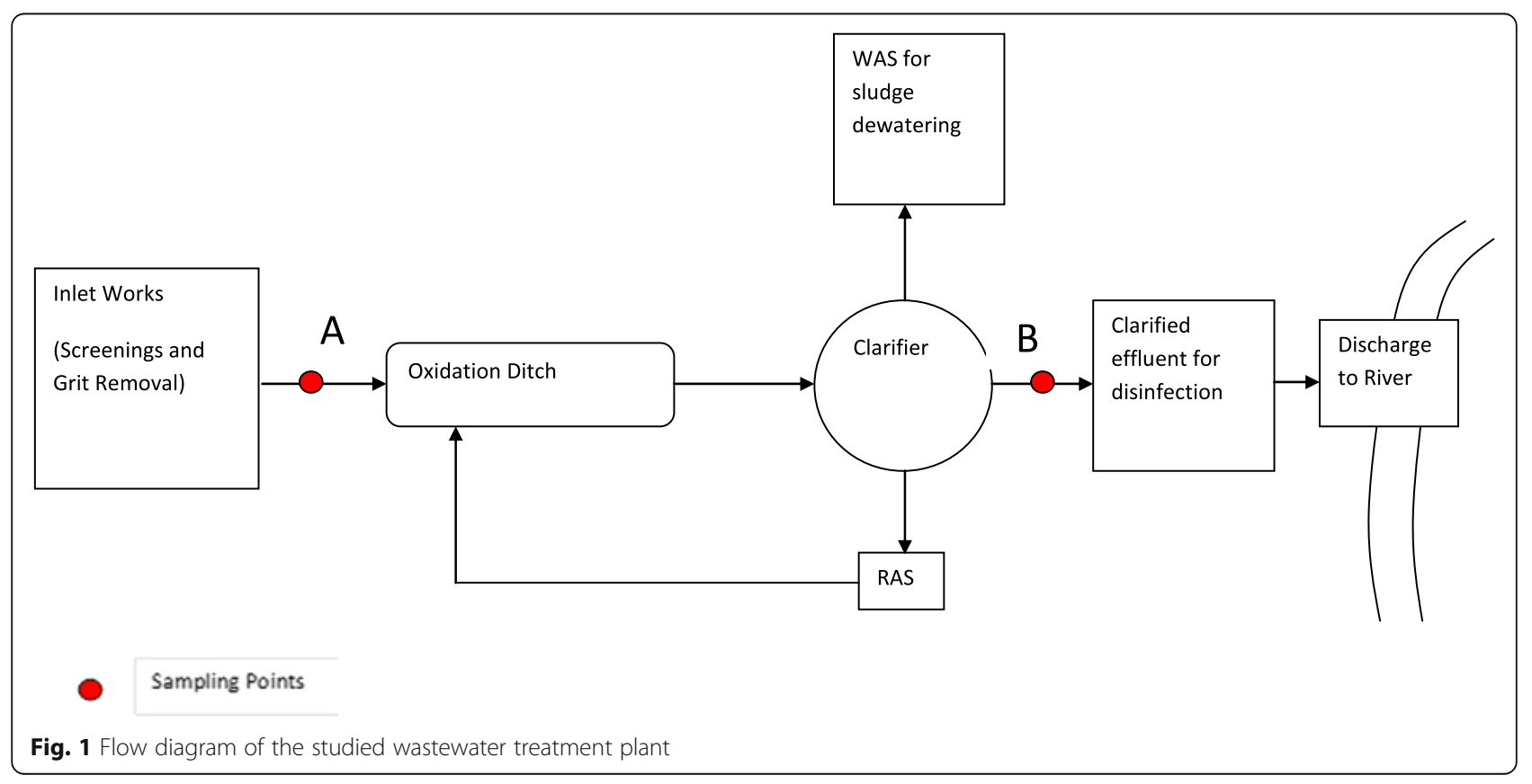


drainage deck (GDD) and a belt filter (BFP) process. The disinfection process uses chlorination. Current average flow rate of influent is $45 \mathrm{ML} /$ day.

Sampling points are shown in Fig. 1 as A and B. Sampling Point A: The wastewater influent, the raw wastewater, was collected after screenings and grit removal. Sampling Point B: The effluent was collected after the biological oxidation ditch and clarifier, but before disinfection of the final effluent. WAS: Waste Activated Sludge, RAS: Return Activated Sludge.

\section{Sampling and analysis}

During September 2012, grab samples were collected in alignment with the Water Monitoring Data Collection Standards of Queensland Government using the methodology described in AS/NZS 5667.1 Water Quality Sampling - Guidance on the design of sampling programs, sampling techniques and the preservation and handling of samples [37-39]. Two sets of samples were collected at two different locations (influent $\mathrm{A}$ and effluent B) of the WWTP on 2 different days. The sampling points were located at two different stages of the treatment plant process: Point A was located after primary treatment and before entering the biological treatment unit (oxidation ditch), while Point B after the biological treatment and clarification process (Fig. 1). In total eight grab samples were collected in $500 \mathrm{ml}$ plastic bottles following the hydraulic retention time (average HRT $=24$ h; i.e., $20 \mathrm{~h}$ in oxidation ditch and $4 \mathrm{~h}$ in clarifier) of the WWTP and together with blank samples were stored at $4{ }^{\circ} \mathrm{C}$ until analysis.

The samples in this study were analysed for a total of 95 compounds, including PPCPs, agricultural, food processing and other micropollutants, which are commonly found in wastewater, using an in-house validated analytical method from Queensland Health Forensic and Scientific Services. This method has been optimised according to the USEPA Method 1694 [40]. A $1 \mathrm{~mL}$ filtered-sample was spiked with mass-labelled chemical standards (compensating for any instrumental variations during analysis) and analysed using liquid chromatography (Shimadzu Prominence, Shimadzu Corp., Kyoto, Japan) coupled with Tandem mass spectrometry (LC-MS/MS; Applied Biosystem/Sciex API 4000Q system). Separation of the compounds was performed on a C18 analytical column (Luna C18, 150X2.1 mm, $3 \mu \mathrm{m}$, Phenomenex) at $45{ }^{\circ} \mathrm{C}$ with a gradient mobile phase (A: $1 \%$ acetonitrile, $99 \%$ Milli-Q water and $0.1 \%$ formic acid; B: $95 \%$ acetonitrile, $5 \%$ Milli-Q water and $0.1 \%$ formic acid) programmed as: $8 \%$ $\mathrm{B}$ at start; ramped up to $35 \% \mathrm{~B}$ at $3.5 \mathrm{~min}$; increased to $100 \% \mathrm{~B}$ at $11 \mathrm{~min}$; held $100 \% \mathrm{~B}$ for 4 mins; equilibration of the column for 3 mins. The mass spectrometry was operated in a multiple reaction monitoring mode to identify and quantify the micropollutants in the samples.

\section{Results}

Wastewater samples were taken at two sampling points before and after the biodegradation step, which has an aerobic and an anaerobic zone and analysed 95 compounds including PPCPs, compounds used in food processing and agriculture by LC-MS/MS. From the two sets of samples collected on two different days (with 5-days apart), during the month of September 2012, the arithmetic average pollutant levels of the two samples were calculated. Out of the 95 compounds tested, we found 38 compounds in the influent, mainly drugs or drug metabolites as shown in Table 2. There were three pesticides and two food components, the artificial sweetener acesulfame and caffeine. Nine of the identified compounds were undetectable in the effluent, but 29 were still present to various degrees in the effluent samples after the biodegradation step in the oxidation ditch.

The majority were removed to at least 80 \% (Fig. 2). The most persistent compounds included MCPA (2methyl-4-chlorophenoxyacetic acid), 2,4-D (2,4-Dichlorophenoxyacetic acid), desmethyl citalopram, phenytoin and carbamazepine (Fig. 2). Surprisingly, acesulfame was removed in the conventional treatment process by $92 \%$ (Fig. 3). Three compounds paracetamol, salicylic acid and caffeine found at concentrations of $289.40 \mu \mathrm{g} / \mathrm{L}$, $32.74 \mu \mathrm{g} / \mathrm{L}$, and $78.09 \mu \mathrm{g} / \mathrm{L}$ respectively in the influent were undetectable in the effluent (Fig. 3).

Tables 3 and 4 present the characteristics of raw wastewater (influent) received by the treatment plant and the quality of treated effluent before disinfection and discharge respectively. The data are typical for water quality of this type of traditional treatment plants. The treatment plant total nitrogen (TN) discharged in the adjacent licensed discharge point is $53 \mathrm{t}$ per year, keeping acceptable levels according to the maximum permitted by regulator (Environment and Heritage Protection) for the river (98 t per year).

\section{Discussion}

The concentrations of observed micropollutants in the wastewater of the investigated WWTP in South-East Queensland were generally within the lower range of previously reported values from around the world [36, 41-45]. This is in agreement with the comparatively low population density in the catchment of the observed WWTP. Where applicable, all values were at least one order of magnitude below the Australian Drinking Water Guidelines 6 [46] and the Australian Guidelines for Water Recycling [47]. In addition, the differences between concentrations of micropollutant parent compounds in influent and effluent water observed in our study fit well within the ranges of current reports from other studies [12, 43].

In the present study, caffeine is at about $80 \mu \mathrm{g} / \mathrm{L}$ in the influent samples. This is about 10 times higher than 
Table 2 List of 95 compounds tested in the influent (The 38 compounds detected in the influent are in bold with 9 compounds absent in effluent shaded)

\begin{tabular}{|c|c|c|}
\hline Atenolol & Phenytoin & Paraxanthine \\
\hline Ranitidine & Oxazepam & Asulam \\
\hline Codeine & Desmethyldiazepam & Diatriozate \\
\hline Gabapentin & Sulfsalazine & lopromide \\
\hline Lincomycin & Temazepam & Hydrochlorthiazide \\
\hline Oxycodone & Naproxen & Acesulfame \\
\hline lopromide & Praziquantel & Acetylsalicylic acid \\
\hline Trimethoprim & Diazepam & Chloramphenicol \\
\hline Doxylamine & Atorvastatin & Salicylic acid \\
\hline Paracetamol & Indomethacin & Frusemide \\
\hline Ciprofloxacin & Diclofenac & Naproxen +Ve \\
\hline Metoprolol & Desisopropyl Atrazine & Warfarin \\
\hline Tramadol & Desethyl Atrazine & Atorvastatin \\
\hline Caffeine & Tebuthiuron & Fluvastatin \\
\hline Sulphadiazine & Hexazinone & Diclofenac \\
\hline Sulphathiazole & Ametryn & Ibuprofen \\
\hline Cephalexin & Bromacil & Gemfibrozol \\
\hline Venlafaxine & Simazine & Dalapon \\
\hline Propranolol & Prometryn & Picloram \\
\hline Primidone & Terbutryn & Fluroxypyr \\
\hline Desmethyl Citalopram & Flumeturon & Dicamba \\
\hline Dapsone & Atrazine & MCPA \\
\hline Erythromycin & Diuron & $24 \mathrm{D}$ \\
\hline Erythromycin hydrate & 3,4 DiCl Aniline & Triclopyr \\
\hline Sulphamethoxazole & Metolachlor & $24 \mathrm{DP}$ \\
\hline Tylosin & Haloxyfop methyl & Mecoprop \\
\hline Ifosfamide & Haloxyfop-ethoxyethyl & $24 \mathrm{DB}$ \\
\hline Cyclophosphamide & Propoxur & MCPB \\
\hline Fluoxetine & Carbaryl & Haloxyfop \\
\hline Sertraline & Diazinon & Asulam \\
\hline Roxithromycin & Chlorpyriphos & Bromoxynil \\
\hline Carbamazepine & Flamprop-M-methyl & \\
\hline
\end{tabular}

the study by Shareef et al., $(8 \mu \mathrm{g} / \mathrm{L}=8000 \mathrm{ng} / \mathrm{L})$ [32]. The difference is reasonable due to the difference of business and human activities, lifestyle, and probably season of the year. Our studied WWTP serves the catchment with about 180,000 people (2011 census). For Oxley and Luggage point, the WWTPs serves about 85,000 and 300,000 people respectively.

With an influent concentration of about $43 \mu \mathrm{g} / \mathrm{L}$, the surprisingly higher reduction (about $92 \%$ ) of acesulfame at the Queensland WWTP is the first report of reduction of this artificial sweetener in a traditional 3-step WWTP at this high level. The QA/QC details are presented below:

Internal standard recovery: $100 \% \pm 3.16 \%$ (mean \pm S.D.) for caffeine and $103 \% \pm 6.84 \%$ for acesulfame.

Variation of duplicate analysis: $<10 \%$ variation (CV\%) for both caffeine and acesulfame. 


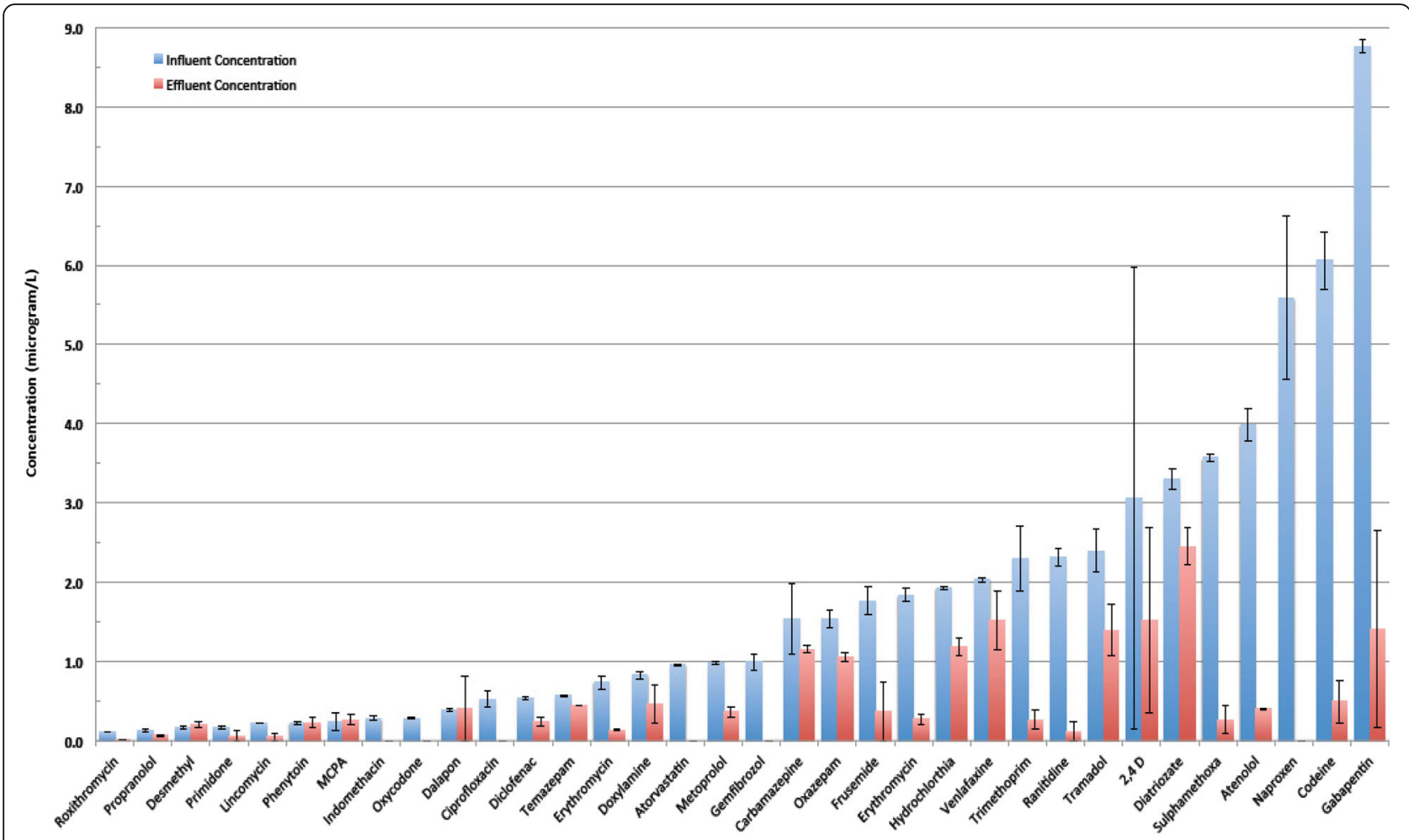

Fig. 2 Removal of micropollutants with low to medium levels of pollutant in the influent (Mean with error bars depicting minimum and maximum observed values)

Inter-day variation: $<20 \%$ (CV\%) for caffeine and $<5 \%$ for acesulfame.

Milli-Q blank samples were included in the batch of analysis. No contamination of these chemicals was found in these blank samples.

Removal rates vary from study to study, which is anticipated as they depend on various conditions including the physico-chemical properties of the compounds and the treatment process itself $[12,43]$. As noted earlier, acesulfame concentrations in the wastewater treatment plant effluents were reported from as low as $20 \mu \mathrm{g} / \mathrm{L}$ (Scheurer et al., 2009) [14] up to higher values as $2.5 \mathrm{mg} / \mathrm{L}$ (Loos et al., 2013) [15]. In the German study [14] acesulfame concentration in the influent to the wastewater treatment plant ranged from 34 to $50 \mu \mathrm{g} / \mathrm{L}$ and up to $41 \%$ removal was observed.

Some compounds are biodegraded by bacteria and in these cases the removal rates can depend on their initial concentration as the removal depends partially on enzyme kinetics [42]. These effects are, however, unlikely to explain sufficiently the extremely high removal rate of ACE found in this study. In previous studies, ACE was removed consistently at $45-65 \%$ by conventional WWT and only additional treatment with ozone or UV light increased the removal rate up to $90 \%[10,16,40,48]$. But ozonation and/or UV light treatment of wastewater as currently practiced in water treatment plants, which prepare drinking water in Switzerland and Germany, reduced the amount of ACE by only $30 \%[10,41,48]$. The detection of a significant amount of unexpected compounds in the wastewater system, in particular the anomolous level of acesulfame removal suggests the need for a detailed assessment. Further investigation of these should use improved analytical protocols.

Our findings also raise questions with regard to the impact of the remaining ACE and its water-soluble degradation products on the environment as well as downstream users of the surface waters. However, degradation of ACE depends on the decomposition process and conditions and many transformation products that have been identified from different processes $[9,10,48]$. It is important to investigate whether the degradation products of $\mathrm{ACE}$ under conventional WWT in SE-Qld conditions are identical to the intermediates and products found in these studies and to assess their toxicological impact on humans and the environment.

While ACE has been substantially tested for its lack of adverse effects to humans before its registration as food additive, only limited data are available about its ecotoxic potential. Ecological toxicity tests using duckweed, Lemna minor, green algae, Scenedesmus vacuolatus, and 


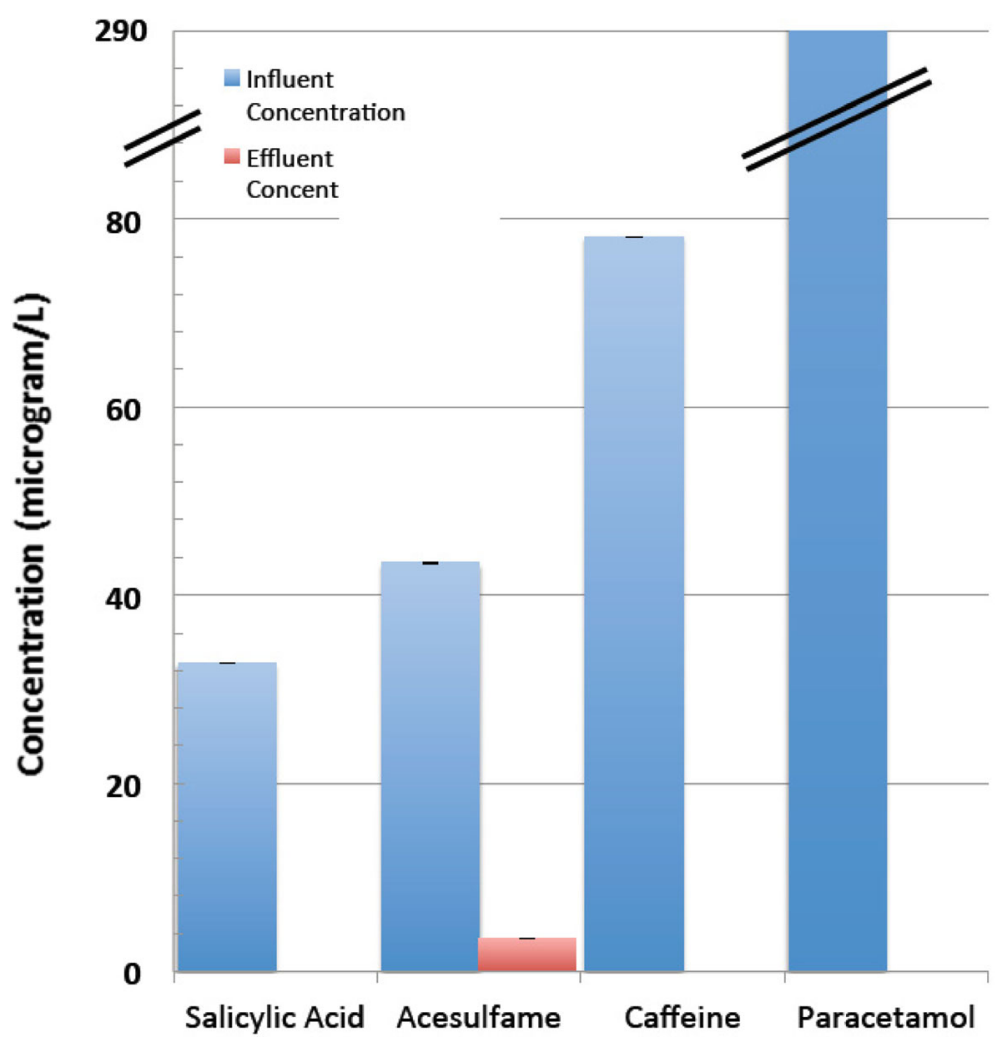

Fig. 3 Removal of micropollutants with high levels of pollutant in the influent (Mean with error bars depicting minimum and maximum observed values)

water fleas, Daphina magna, revealed very high Lowest Observed Effect Concentrations (LOEC) for ACE [49].

In recent years, detection of micropollutants in wastewater and surface waters has inspired the search for practicalities beyond monitoring of their discharge into ecosystems. Monitoring the use of specific drugs, including illicit drugs, through wastewater analysis in regions and countries has become common, for example to estimate illicit drug use per capita or to monitor increases over holiday periods
[50, 51]. Individual micro-constituents, such as the drugs valsartan acid, carbamapezine and the artificial sweetener acesulfame, were identified to have physicochemical properties, which makes them resistant to degradation in wastewater treatment plants. This persistence has led to the concept of using them as tracers and markers in water bodies e.g., for identification of groundwater contamination with urban wastewater [52]. In fact, removal rate of carbamazepine in our study was also poor

Table 3 Inlet wastewater quality

\begin{tabular}{|c|c|c|c|c|c|c|c|c|c|c|c|}
\hline Date & $\mathrm{pH}$ & $\begin{array}{l}\mathrm{NH}_{3} \\
\mathrm{mg} / \mathrm{L}\end{array}$ & $\begin{array}{l}\mathrm{NOx}-\mathrm{N} \\
\mathrm{mg} / \mathrm{L}\end{array}$ & $\begin{array}{l}\text { ortho- } \mathrm{PO}_{4}-\mathrm{P} \\
\mathrm{mg} / \mathrm{L}\end{array}$ & $\begin{array}{l}\mathrm{TP} \\
\mathrm{mg} / \mathrm{L}\end{array}$ & $\begin{array}{l}\text { TN } \\
\mathrm{mg} / \mathrm{L}\end{array}$ & $\begin{array}{l}\text { TSS } \\
\mathrm{mg} / \mathrm{L}\end{array}$ & $\begin{array}{l}\text { TKN } \\
\mathrm{mg} / \mathrm{L}\end{array}$ & $\begin{array}{l}\mathrm{COD} \\
\mathrm{mg} / \mathrm{L}\end{array}$ & $\begin{array}{l}\mathrm{BOD} \\
\mathrm{mg} / \mathrm{L}\end{array}$ & $\begin{array}{l}\text { Alkalinity } \\
\mathrm{mg} / \mathrm{L} \\
\left(\mathrm{CaCO}_{3}\right)\end{array}$ \\
\hline 3/09/2012 & 7.5 & 66 & 0.2 & 7.7 & 8.7 & 71 & 330 & 71 & 760 & 460 & 340 \\
\hline $5 / 09 / 2012$ & 7.1 & 74 & 0.1 & 7.7 & 8.2 & 76 & 370 & 76 & 800 & 440 & 350 \\
\hline 10/09/2012 & 7.9 & 49 & 0.4 & 7.0 & 7.0 & 73 & 560 & 73 & 750 & 620 & 330 \\
\hline $12 / 09 / 2012$ & 7.5 & 54 & 0.2 & 8.0 & 11.0 & 87 & 580 & 87 & 1180 & 700 & 370 \\
\hline 17/09/2012 & 7.6 & 46 & 0.1 & 6.8 & 10.0 & 70 & 390 & 70 & 830 & 480 & 340 \\
\hline 19/09/2012 & 7.6 & 58 & 0.1 & 7.4 & 7.9 & 83 & 950 & 83 & 950 & 618 & 370 \\
\hline 24/09/2012 & 7.7 & 50 & 0.1 & 6.9 & 10.0 & 69 & 420 & 69 & 810 & 540 & 370 \\
\hline 26/09/2012 & 7.5 & 63 & 0.1 & 7.7 & 10.0 & 80 & 510 & 80 & 960 & 540 & 370 \\
\hline
\end{tabular}

TN total nitrogen, TP total phosphorus, TSS total suspended solids, TKN total Kjedahl nitrogen, COD chemical oxygen demand, BOD biochemical oxygen demand 
Table 4 Quality of treated effluent after clarification

\begin{tabular}{lcccccc}
\hline Date & $\begin{array}{l}\mathrm{NH}_{3} \\
\mathrm{mg} / \mathrm{L}\end{array}$ & $\begin{array}{l}\mathrm{NOx} \\
\mathrm{mg} / \mathrm{L}\end{array}$ & $\begin{array}{l}\text { ortho } \mathrm{PO}_{4}-\mathrm{P} \\
\mathrm{mg} / \mathrm{L}\end{array}$ & $\mathrm{pH}$ & $\begin{array}{l}\mathrm{TSS} \\
\mathrm{mg} / \mathrm{L}\end{array}$ & $\begin{array}{l}\mathrm{TP} \\
\mathrm{mg} / \mathrm{L}\end{array}$ \\
\hline $3 / 09 / 2012$ & 2.1 & 0.7 & 3.2 & 7.6 & 4 & 3.4 \\
$5 / 09 / 2012$ & 1.7 & 0.8 & 3.7 & 7.6 & 5 & 3.9 \\
$10 / 09 / 2012$ & 0.8 & 0.7 & 2.9 & 7.8 & 6 & 3.1 \\
$12 / 09 / 2012$ & 0.7 & 0.7 & 4.3 & 7.6 & 6 & 4.6 \\
$17 / 09 / 2012$ & 0.9 & 0.7 & 4.1 & 7.7 & 7 & 4.2 \\
$19 / 09 / 2012$ & 0.1 & 1.8 & 5.6 & 7.5 & 3 & 5.8 \\
$24 / 09 / 2012$ & 0.4 & 0.4 & 2.6 & 7.7 & 7 & 2.8 \\
$26 / 09 / 2012$ & 0.3 & 0.7 & 3.4 & 7.7 & 7 & 3.6 \\
\hline
\end{tabular}

$T N$ total nitrogen, TP total phosphorus, TSS total suspended solids

( $20 \%)$. In light of our results with acesulfame it appears relevant to consider environmental conditions on local removal efficiencies of such tracers for appropriate interpretation of quantitative results in particular.

\section{Conclusions}

The presence of 95 common micropollutants of domestic, industrial and agricultural, including pharmaceuticals, personal care products (PCPPs) and food components was determined in the wastewater influent and effluent of a particular WWTP in SE-Qld. Thirty eight compounds were found in the influent. Although this is a relatively simple conventional wastewater treatment, the levels of most of these chemicals were reduced similarly to the extent in more sophisticated WWTP, particularly regarding anti-inflammatory drugs, analgesics and antibacterials. Surprisingly, more than $90 \%$ of the artificial sweetener acesulfame was removed in this WWTP. This anomolous level of acesulfame removal suggests the need for a detailed assessment.

Nine of the compounds in the categories of analgesic, anti-inflammatory, alkaloid and lipid/cholesterol lowering drugs were undetectable (100\% removed) in the effluent. They were: Analgesic: Paracetamol, Salicylic acid, Oxycodone; Anti-inflammatory: Naproxen + ve, Atorvastatin, Indomethacin, Naproxen; Alkaloid: Caffeine; Lipid/cholesterol lowering: Gemfibrozol.

\section{Abbreviations}

ACE: Acesulfame; AS: Artificial sweeteners; EDC: Endocrine disrupting compounds; HRT: Hydraulic retention time; LC-MS/MS: Liquid chromatography coupled with Tandem mass spectrometry; PPCPs: Pharmaceuticals and personal care products; WWTPs: Wastewater treatment plants

\section{Acknowledgements}

We greatly acknowledge the support provided by the management and operational staff of the WWTP in the investigations and the City Council for granting permission to publish the findings.

Steve Carter (Queensland Health Forensic Scientific Services, Special Services, Organic Chemistry) provided access to LC-MS/MS for the sample analysis. The support of Professor Jochen Mueller (EnTox) and Dr Phong Thai (EnTox) with assistance in sample collection and preparation is greatly acknowledged. Thanks are due to Dr Paul Burrell of QUT for proof reading the manuscript.

\section{Funding}

Financial support provided by the School of Earth, Environmental and Biological Sciences (EEBS) of the Queensland University of Technology (QUT), under special projects, BEN910/2012.

\section{Availability of data and materials}

All data generated or analysed during this study are included in this published article. Additional information may be available from the corresponding author on reasonable request.

Authors' contributions

$M A, I A, J R, R T$ and $L D$ contributed to drafting and editing the manuscript. $Y L$ contributed to sample analysis, interpretation of results and editing the manuscript. All authors read and approved the final manuscript.

\section{Competing interests}

The authors declare that they have no competing interests.

Consent for publication

Not applicable.

Ethics approval and consent to participate

Not applicable.

\section{Author details}

${ }^{1}$ MI Murrumbidgee Irrigation, Research Station Road, Hanwood, NSW 2680, Australia. ${ }^{2}$ Treatment Program, Logan City Council, Logan City DC, QLD 4114, Australia. ${ }^{3}$ National Research Centre for Environmental Toxicilogy (EnTox), The University of Queensland, Brisbane, QLD 4108, Australia. ${ }^{4}$ Science and Engineering Faculty, School of Earth, Environment and Biological Sciences, Queensland University of Technology, QLD 4001 Brisbane, Australia. ${ }^{5}$ Faculty of Health, Queensland University of Technology, QLD 4001 Brisbane, Australia.

Received: 14 May 2015 Accepted: 3 October 2016

Published online: 03 November 2016

References

1. Jones $\mathrm{OAH}$, Lester JN, Voulvoulis N. Pharmaceuticals: a threat to drinking water? Trends Biotechnol. 2005;24:163-7.

2. Australian Government: Land \& Water Australia.Targeting Endocrine Disruptors in Australia's Water Ways. 2008; www.lwa.gov.au: Product code PN22054: ISBN 97819215444262 Available at: http://pandora.nla.gov.au/ pan/103522/20091110-1348/Iwa.gov.au/files/products/innovation/pn22054/ pn22054.pdf. Accessed 08 May 2015.

3. Environment Protection and Heritage Council. National Framework for Chemicals Management in Australia - Discussion Paper [Online]. Australian Government, 2006. Available at: http://www.nepc.gov.au/system/files/ resources/74b7657d-04ce-b214-d5d7-51dcbce2a231/files/cmgt-nchemdiscppr-national-framework-chemicals-management-australia-200607.pdf. Accessed 20 October 2012

4. EPA South Australia. Risks from endocrine disrupting substances in the South Australian aquatic environment. Adelaide: Environmental Protection Authority, 2008 Available at: http://www.epa.sa.gov.au/xstd_files/Water/ Report/risks endocrine.pdf. Accessed 20 October 2012.

5. Helland J. Endocrine Disrupters as Emerging Contaminants in Wastewater. Minnesota Minessota House of Representatives: Research Department, 2006. Available at: http://www.house.leg.state.mn.us/hrd/pubs/endodis.pdf.

6. Kuspis D, Krenzelok E. What happens to expired medications? a survey of community medication disposal. US national library of medicine. Vet Hum Toxicol. 1996:38(1):48-9.

7. Ahel M, Mikac N, Cosovic B, Prohic E, Soukup V. The impact of contamination from a municipal solid waste landfill (zagreb, croatia) on underlying soil. Water Sci Technol. 1998:37:203-10.

8. WHO. International Program of Chemical Safety: Global Assessment of the State of the Science of Endocrine Disruptors World Health Organization. 2002. Available at: http://www.who.int/ipcs/publications/new_issues/ endocrine disruptors/en/.

9. Sang $Z$, Jiang $Y$, Tsoi YK, Leung KS. Evaluating the environmental impact of artificial sweeteners: a study of their distributions, photodegradation and toxicities. Water Res. 2014;52:260-74. 
10. Scheurer M, Schmutz B, Happel O, Brauch HJ, Wülser R, Storck FR. Transformation of the artificial sweetener acesulfame by UV light. Sci Total Environ. 2014;15:425-32.

11. Kokotou MG, Asimakopoulos AG, Thomaidis NS. Artificial sweeteners as emerging pollutants in the environment: analytical methodologies and environmental impact. Anal Methods. 2012;4(10):3057-70.

12. Lange FT, Scheurer M, Brauch HJ. Artificial sweeteners-a recently recognized class of emerging environmental contaminants: a review. Anal Bioanal Chem. 2012;403(9):2503-18

13. Gan Z, Sun H, Feng B, Wang R, Zhang Y. Occurrence of seven artificial sweeteners in the aquatic environment and precipitation of Tianjin, China. Water Res. 2013;47(14):4928-37.

14. Scheurer M, Brauch HJ, Lange FT. Analysis and occurrence of seven artificial sweeteners in German waste water and surface water and in soil aquifer treatment (SAT). Anal Bioanal Chem. 2009;394(6):1585-94. doi:10.1007/s00216-009-2881-y. Epub 2009 Jun 16.

15. Loos R, Carvalho R, António DC, Comero S, Locoro G, Tavazzi S, Paracchini B, Ghiani M, Lettieri T, Blaha L, Jarosova B, Voorspoels S, Servaes K, Haglund P, Fick J, Lindberg RH, Schwesig D, Gawlik BM. EU-wide monitoring survey on emerging polar organic contaminants in Wastewater treatment plant effluents. Water Res. 2013;47(17):6475-87. doi:10.1016/j.watres.2013.08.024. Epub 2013 Sep 15

16. Buerge IJ, Buser H-R, Kahle M, Müller MD, Poiger T. Ubiquitous occurrence of the artificial sweetener acesulfame in the aquatic environment: an ideal chemical marker of domestic wastewater in groundwater. Environ Sci Technol. 2009:43(12):4381-5.

17. Jackson J, Sutton R. Sources of endocrine-disrupting chemicals in urban wastewater, Oakland, CA. Sci Total Environ. 2008:405:153-60.

18. Evans R, Kortenkamp A, Martin O, McKinlay R, Orton F \& Rosivatz E. State of the art assessment of Endocrine Disrupters, 2nd Interim Report. 2011; Project Contract Number 070307/2009/550687/SER/D3.

19. Burns CJ, Swaen G. Review of 2,4-dichlorophenoxyacetic acid (2,4-D) biomonitoring and epidemiology. Crit Rev Toxicol. 2012;42(9):768-86.

20. Garcia-Käufer M, Haddad T, Bergheim M, Gminski R, Gupta P, Mathur N, Kümmerer K, Mersch-Sundermann V. Genotoxic effect of ciprofloxacin during photolytic decomposition monitored by the in vitro micronucleus test (MNvit) in HepG2 cells. Environ Sci Pollut Res. 2012;19:1719-27.

21. Ahmad M, Khan AU, Wahid A, Ali AS, Ahmad F. Role of untreated waste water in spread of antibiotics and antibiotic resistant bacteria in river. Pak J Sci. 2013:65(1):10-4.

22. Thuy HTT, Nguyen TD. The potential environmental risks of pharmaceuticals in Vietnamese aquatic systems: case study of antibiotics and synthetic hormones. Environ Sci Pollut Res. 2013;20:8132-40.

23. Vaz-Moreira I, Nunes OC, Manaia CM. Bacterial diversity and antibiotic resistance in water habitats: searching the links with the human microbiome. FEMS Microbiol Rev. 2014;38:761-78.

24. WHO. Antimicrobial resistance: global report on surveillance 2014, World Health Organization. 2014. ISBN 978924156474 8. Available at: http://www.who.int/ drugresistance/documents/surveillancereport/en/. Accessed 6 Oct 2016.

25. Escher BI, Bramaz N, Mueller JF, Quayle P, Rutishauser S, Vermeirssen EL. Toxic equivalent concentrations (TEQs) for baseline toxicity and specific modes of action as a tool to improve interpretation of ecotoxicity testing of environmental samples. J Environ Monit. 2008;10(5):612-21.

26. Escher BI, Bramaz N, Quayle P, Rutishauser S, Vermeirssen EL. Monitoring of the ecotoxicological hazard potential by polar organic micropollutants in sewage treatment plants and surface waters using a mode-of-action based test battery. J Environ Monit. 2008;10(5):622-31.

27. Macova M, Escher Bl, Reungoat J, Carswell S, Chue KL, Keller J, Mueller JF. Monitoring the biological activity of micropollutants during advanced wastewater treatment with ozonation and activated carbon filtration. Water Res. 2010:44:477-92

28. Reungoat J, Escher BI, Macova M, Mueller JF, Carswell S, Keller J. Removal of micropollutants and reduction of biological activity in a full scale reclamation plant using ozonation and activated carbon filtration. Water Res. 2010;44:625-37.

29. Reungoat J, Escher BI, Macova M, Keller J. Biofiltration of wastewater treatment plant effluent: Effective removal of pharmaceuticals and personal care products and reduction of toxicity. Water Res. 2011;45:2751-62.

30. Reungoat J, Escher BI, Macova M, Argaud FX, Gernjak W, Keller J. Ozonation and biological activated carbon filtration of wastewater treatment plant effluents. Water Res. 2012;46:863-72.
31. Jekel M, Dott W, Bergmann A, Dünnbier U, Gnirß R, Haist-Gulde B, Hamscher G, Letzel M, Licha T, Lyko S, Miehe U, Sacher F, Scheurer M, Schmidt CK, Reemtsma T, Ruhl AS. Selection of organic process and source indicator substances for the anthropogenically influenced water cycle. Chemosphere. 2015;125:155-67.

32. Shareef A, Williams M, Kookana R. Concentration of selected endocrine disrupting chemicals and pharmaceutical and personal care products entering wastewater treatment plants in South East Queensland. Urban Water Security Research Alliance, 2010; Technical Report No. 20.

33. Ying GG, Kookana RS, Kumar A, Mortimer M. Occurrence and implications of estrogens and xenoestrogens in sewage effluents and receiving waters from South East Queensland. Science of The Total Environment. 2009:407(18):5147-55.

34. Tan BLL, Hawker DW, Muller JF, Leusch FDL, Tremblay LA, Chapman HF. Comprehensive study of endocrine disrupting compounds using grab and passive sampling at selected wastewater treatment plants in South East Queensland, Australia. Environ Int. 2007;33:654-69.

35. Watkinson AJ, Murby EJ, Costanzo SD. Removal of antibiotics in conventional and advanced wastewater treatment: Implications for environmental discharge and wastewater recycling. Water Res. 2007;41:4164-76

36. Watkinson AJ, Murby EJ, Kolpine DW, Costanzo SD. The occurrence of antibiotics inan urban watershed: From wastewater to drinking water. Sci Total Environ. 2009:407:2711-23.

37. Queensland Government. In: Department of Natural Resources and Water, editor. Water monitoring data collection standards. Brisbane: Queensland Government; 2007.

38. Standards Australia. Water quality - Sampling - Guidance on the design of sampling programs, sampling techniques and the preservation and handling of samples. Canberra: Standards Australia; 1997.

39. Standards Australia. Water quality-Sampling — Guidance on sampling of waste waters. Canberra: Standards Australia; 1998.

40. U.S. Environmental Protection Agency. Method 1694: Pharmaceuticals and Personal Care Products in Water, Soil, Sediment, and Biosolids by HPLC/MS/ MS; Office of Water, Office of Science and Technology, Engineering and Analysis Division (4303 T): Washington DC, 2007; p77.

41. Ndler K, Hillebrand O, Idzik K, Strathmann M, Schiperski F, Zirlewagen J, Licha T. Occurrence and fate of the angiotensin II receptor antagonist transformation product valsartan acid in the water cycle - A comparative study with selected $\beta$-blockers and the persistent anthropogenic wastewater indicators carbamazepine and acesulfame. Water Res. 2013;47:6650-9.

42. Onesios-Barry KM, Berry D, Proescher JB, Sivakumar IK, Bouwer EJ. Removal of pharmaceuticals and personal care products during water recycling: microbial community structure and effects of substrate concentration. Appl Environ Microbiol. 2014;80(8):2440-50.

43. Luo Y, Guoa W, Ngo HH, Nghiemb LD, Hai Fl, Zhang J, Liang S, Wang XC. A review on the occurrence of micropollutants in the aquatic environment and their fate and removal during wastewater treatment. Sci Total Environ. 2014:473-474:619-41.

44. Mohapatra DP, Brar SK, Tyagi RD, Picard P, Surampalli RY. Analysis and advanced oxidation treatment of a persistent pharmaceutical compound in wastewater and wastewater sludge-carbamazepine. Sci Total Environ. 2014;470-471:58-75.

45. Yang X, Riley C, Flowers B, Howard S, Weinberg B, Philip C, Singer B. Occurrence and removal of pharmaceuticals and personal care products (PPCPS) in an advanced wastewater reclamation plant. Water Res. 2011;45:5218-28.

46. NHMRC, NRMMC. Australian Drinking Water Guidelines Paper 6 National Water Quality Management Strategy. National Health and Medical Research Council, National Resource Management Ministerial Council, Commonwealth of Australia, Canberra. 2011. Version 2 (Updated and published 2013) Available at: https://www.clearwater.asn.au/user-data/ resource-files/Aust_drinking_water_guidelines.pdf. Accessed 05 May 2015.

47. NRMMC-EPHC-NHMRC. Australian Guidelines for Water Recycling: Augmentation of Drinking Water Supplies. Natural Resource Management Ministerial Council-Environment, Protection and Heritage Council-National Health and Australian Medical Research Council, Canberra. 2008. Available at: http://www.environment.gov.au/system/files/resources/9e4c2a10-fcee48ab-a655-c4c045a615d0/files/water-recycling-guidelines-augmentationdrinking-22.pdf. Accessed 05 May 2015. 
48. Scheurer M, Storck FR, Brauch HJ, Lange FT. Performance of conventional multi-barrier drinking water treatment plants for the removal of four artificial sweeteners. Water Res. 2010;44(12):3573-84.

49. Stolte S, Steudte S, Schebb NH, Willenberg I, Stepnowski P. Ecotoxicity of artificial sweeteners and stevioside. Environ Int. 2013;60:123-7.

50. Lai FY, Ort C, Gartner C, Carter S, Prichard J, Kirkbride P, Bruno R, Hall W, Eaglesham G, Mueller JF. Refining the estimation of illicit drug consumptions from wastewater analysis: co-analysis of prescription pharmaceuticals and uncertainty assessment. Water Res. 2011;45(15):4437-48.

51. Ort C, Eppler JM, Scheidegger A, Rieckermann J, Kinzig M, Sörgel F. Challenges of surveying wastewater drug loads of small populations and generalizable aspects on optimizing monitoring design. Addiction. 2014;109(3):472-81.

52. Stuart ME, Lapworth DJ, Thomas J, Edwards L. Fingerprinting groundwater pollution in catchments with contrasting contaminant sources using microorganic compounds. Sci Total Environ. 2014:15:468-9. 564-77.

53. Bound J, Voulvoulis N. Household disposal of pharmaceuticals as a pathway for aquatic contamination in the United Kingdom. Environ Health Perspect. 2005;113:1705-11.

54. Huschek G, Hansen P, Maurer H, Krengler D, Kayser A. Environmental risk assessment of medicinal products for human use according to European commission recommendations. Environ Toxicol. 2004;19:226-40.

55. Hirsch R, Ternes T, Haberer K, Kratz KL. Occurrence of antibiotics in the aquatic environment. Sci Total Environ. 1999;225:109-18.

\section{Submit your next manuscript to BioMed Central and we will help you at every step:}

- We accept pre-submission inquiries

- Our selector tool helps you to find the most relevant journal

- We provide round the clock customer support

- Convenient online submission

- Thorough peer review

- Inclusion in PubMed and all major indexing services

- Maximum visibility for your research

Submit your manuscript at www.biomedcentral.com/submit 